\title{
Micropropagation of Endangered and Decorative Species Dianthus pinifolius Sibth. et Sm.
}

\author{
Marija Markovic $^{1}{ }^{*}$; Mihailo Grbic ${ }^{1}$; Matilda Djukic ${ }^{1}$ \\ ${ }^{I}$ University of Belgrade, Faculty of Forestry, Serbial;
}

\begin{abstract}
The aim of this study was to establish an efficient protocol for the in vitro propagation of the endangered, endemic and decorative species Dianthus pinifolius Sibth. et Sm. The effects of different concentrations of 6benzylaminopurine (BAP) and naphtalenacetic acid (NAA), and different explant types (single-node cuttings, terminal buds and shoot cuttings) on shoot multiplication were examined on Murashige and Skoog (MS) and halfstrength MS media. The best results were obtained for shoot cuttings on the MS medium supplemented with 0.5 $\mathrm{mg} / \mathrm{L} \mathrm{BAP}$ and $0.1 \mathrm{mg} / \mathrm{L} \mathrm{NAA}$, achieving a maximum rate of regeneration $(100 \%)$ and a total of 15.4 newlydeveloped shoots per explant. The highest rooting rate (96.7\%) was obtained on MS medium containing $1 \mathrm{mg} / \mathrm{L}$ NAA, while the acclimatization of the microplants obtained to ex vitro conditions was successful (88.9\%).
\end{abstract}

Key words: pineleaf pink, in vitro culture, BAP, NAA, multiplication

*Author for correspondence: marija.markovic@sfb.bg.ac.rs 


\section{INTRODUCTION}

The endemic species of the southeastern Balkans (Tomović et al. 2003) Dianthus pinifolius Sibth. et $\mathrm{Sm}$. (Caryophyllaceae) isincluded in category $\mathrm{V}$ (vulnerable taxa) in Serbia and protected by law asan endangered plant species (Law on Environmental Protection, Rulebook on protected species 2010). Although, D. pinifolius can be found at several localities in Serbia,it is present in small numbers, occurringin its natural habitats (Tomović et al. 2003).This species grows on dry, brushy and grassy siliceous stony ground, and blooms in summer withpurple or violet flowers (Gajić 1970; Ranđelović et al. 2008). Thanks to its bluish-green leaves, $D$. pinifoliusis decorative throughout thevegetation period andparticularlywell-suited for cottage gardens. Due to its low-maintenance requirements, and the fact that it is a native species that fits in a natural environment without adverse impacts on the surrounding natural ecosystems, D. pinifolius is suitable for planting in Serbian mountain resorts, which is in accordance with the increasingly dominating trend of naturalistic garden design that involves wild plant species (Marković 2013).

Population of $D$. pinifolius in Mt Kopaonik is situated in protected area which was protected as a National Park by the proclamation of the Law on the Protection of the National Park Kopaonik (Official Gazette RS, 41/81, 44/93). To enable its ex situ and in situ conservation, we decided to propagate $D$. pinifolius. However, large amount of seeds could not be collected due to its threatened stratus.

As the most suitable method for rapid propagation of endangered taxais micropropagation (Pence 1999), many studies have so far been published on the micropropagation of the endangered Dianthus species in the Balkans, mostly in Romania and Serbia. These studies includeD.petraeus Waldst. $\&$ Kit. ssp. noeanus (Boiss.) Tutin, D.giganteus d'Urv. ssp. croaticus (Borbás) Tutin, D. ciliatus Guss. ssp. dalmaticus (Čelak.) Hayek (Radojevićet al. 1997; 2006; 2010), and D. serotinus Waldst. et Kit. (Marković et al. 2007, 2013a), which were investigated in Serbia. Several species such as D. callizonus Schott \& Kotschy (Holobiuc andBlindu 2006), D. glacialis Haenke ssp. gelidus (Schott, Nym. et Kotschy) Tutin (Holobiucet al. 2010a), D. giganteusd'Urv. subsp. banaticus (Heuff. Ex Griseb. \& Schenk) Tutin (Pop and Pamfil 2011), D.henteri Heuff. ex Griseb. \& Schenk (Cristeaet al. 2010), D. petraeus Waldst. \& Kit. ssp. simonkaianus (Péterfi) Tutin (Miclăuşet al. 2003), D. pratensis M. Bieb. subsp. racovitzae (Prodan) Tutin (Cristea 2010), D.nardiformis Janka (Holobiucet al. 2009; 2010b) and D. spiculifolius Schur (Butiuc-Keul et al. 2001) were studied in Romania.

The above studies havemainly investigated the optimum concentration of phytohormones added to culture media, which differed depending on the species. As therewere no published results regarding the micropropagation of $D$. pinifolius, the aim of this study was to establish a protocol for simple and rapid micropropagation of thisendangered, endemic and decorative species.

\section{MATERIAL AND METHODS}

The seed capsules of $D$. pinifolius were collected from different plants randomly, on Mt. Kopaonik. The seeds were taken from capsules in the laboratory and surface disinfected by immersion in $4 \% \mathrm{NaOCl}$ supplemented with 3 4 drops of the Tween 20 (Sigma) for $20 \mathrm{~min}$. After rinsing three timesin sterile distilled water, they were used forgerminationon hormone-free MS medium (Murashige and Skoog 1962). In all the experiments, the media used wereMS basal medium and half-strength MS basal medium supplemented with $3 \%(\mathrm{w} / \mathrm{v})$ sucrose and $0.8 \%$ $(\mathrm{w} / \mathrm{v})$ agar, and the $\mathrm{pH}$ was adjusted to 5.8 before autoclaving at $121^{\circ} \mathrm{C}$ for $20 \mathrm{~min}$. The effects of plant growth regulators on shoot initiation and multiplication were studied at the multiplication stage. The culturing of explants (single-node cuttings, terminal buds and shoot cuttingswith one node) was performed in 200 $\mathrm{mL}$ glass vessels (five explants/vessel) containing $25 \mathrm{~mL}$ of the medium (MS, or halfstrength MS) supplemented with $0.1,0.5$, or 1.0 $\mathrm{mg} / \mathrm{Lof}$ BAP and 0.1 , or $0.5 \mathrm{mg} / \mathrm{Lof}$ NAA, while each experiment had threereplications including 20 explants in eachtreatment. After 25 days in culture, both the number of shoots and nodes produced per explant and shoot and internode lengths were recorded.Basal MS or half strength MS media supplemented with NAA $(0.05,0.1$, 
$0.5 \mathrm{mg} / \mathrm{L})$ or without growth regulators were used to induce rooting. At the rooting stage,the shoots (10-35 mm long) were cultured in 720 $\mathrm{mL}$ glass vessels (15 explants/vessel), containing $100 \mathrm{~mL}$ of the medium. Thirty explants were cultured in each treatment, which wasreplicated three times. The percentage of shoots forming roots was quantified, as well as the number of roots per rooted shoot; root length was measured after 15 days. After the cultures were grown at $24 \pm 2^{\circ} \mathrm{C}$, under a $16 / 8 \mathrm{~h}$ photoperiod and light intensity of $50 \mu \mathrm{mol} / \mathrm{m}^{2} \mathrm{~s}$ provided by fluorescent tubes ("Tesla" Pančevo).The 90 uniformly rooted plantlets were acclimatized in a 1: 1 mixture of peat and sand, treated with a $1.5 \%$ solution of Previcur-N fungicide before use. During the first 15 days of acclimatization,the plants were covered with perforated plastic wrap to maintain high relative humidity, while ventilation was applied once daily for 5-10 min. Following the removal of the plastic wrap, the plants were grown for 10 more days before recording their survival rate.

The program Statgraphics, version 5.0 (STSC Inc. and Statistical Graphics Corporation, 19942000, USA) was used to statistically analyze the data, whereas the significance of differences between the mean values was determined by the analysis of variance (ANOVA, p <0.05) and the method of least significant difference (LSD).

\section{RESULTS AND DISCUSSION}

Results showed that the in vitro culture was successfully established from the seeds, since the obtained germination rate of $92 \%$ was high compared to the values recorded forsome other Dianthus species, includingD. deltoides-58\%
(Popović et al. 2008), D. ciliatus ssp. dalmaticus - 70\%, D. giganteus ssp. croaticus 42\% (Radojević et al. 2010) and D. henteri $75 \%$ (Cristea et al. 2010). Similarly, a high germination percentage was also recorded for $D$. giganteiformis ssp. kladovanus - $88 \%$ (Marković et al. 2006) andD. serotinus - 97\% (Marković et al. 2007). Besides being affected by the species, germination ratecan also be influenced by thesterilizing agent and duration of the treatment. The most commonly used $\mathrm{NaOCl}$ and $\mathrm{H}_{2} \mathrm{O}_{2}$ are oxidizing agents, whichhave also been reported to have a stimulatory effect on seed germination in some species. This is reflected in the partial degradation of the seed coat and solubilization and oxidation of the inhibitorsof seed germination(Frank and Larson 1970; Miyoshi and Mii 1995; 1998; Lee et al. 2007). The germination of some Dianthus species couldalso be affected by light conditions, asMarcu et al. (2006) found that D. pyrenaicus germinated better in light $-90 \%$ than in darkness $-70 \%$.

Atthe multiplication stage, the percentage of shoot regeneration (Table 1) was high on all the media tested, ranging between 91.7 and 100\%, whereas the best results were obtained on the medium with $0.1 \mathrm{mg} / \mathrm{L} \mathrm{BAP}$ and $0.1 \mathrm{mg} / \mathrm{L} \mathrm{NAA}$ (100\% - for all explant types). There were no records of vitrification, whereas the concentration of MS salts (MS or half-strength MS) did not affect the frequency of shoot regeneration. However, in some other Dianthus species, such as D. serotinus, theconcentration of MS salts significantly affected shoot regeneration, showing better results on halfstrength MS media (Marković et al. 2013a).

Table 1- Shoot regeneration on MS and half strength MS (1/2 MS) medium

\begin{tabular}{cccccccc}
\hline BAP & NAA & \multicolumn{2}{c}{ single node cuttings $(\%)$} & \multicolumn{2}{c}{ terminal buds $(\%)$} & \multicolumn{2}{c}{ shoot cuttings $(\%)$} \\
\cline { 3 - 8 } mg/L & mg/L & $1 / 2 \mathrm{MS}$ & MS & $1 / 2 \mathrm{MS}$ & MS & $1 / 2 \mathrm{MS}$ & MS \\
\hline 1.0 & 0.5 & $91.7^{\mathrm{b}}$ & $93.3^{\mathrm{b}}$ & $95.0^{\mathrm{ab}}$ & $95.0^{\mathrm{a}}$ & $93.3^{\mathrm{b}}$ & $95.0^{\mathrm{a}}$ \\
\hline 1.0 & 0.1 & $95.0^{\mathrm{ab}}$ & $96.7^{\mathrm{ab}}$ & $93.3^{\mathrm{ab}}$ & $96.7^{\mathrm{a}}$ & $95.0^{\mathrm{ab}}$ & $95.0^{\mathrm{a}}$ \\
\hline 0.5 & 0.5 & $95.0^{\mathrm{ab}}$ & $98.3^{\mathrm{ab}}$ & $95.0^{\mathrm{ab}}$ & $96.7^{\mathrm{a}}$ & $93.3^{\mathrm{b}}$ & $96.7^{\mathrm{a}}$ \\
\hline 0.5 & 0.1 & $96.7^{\mathrm{ab}}$ & $96.7^{\mathrm{ab}}$ & $100.0^{\mathrm{a}}$ & $100.0^{\mathrm{a}}$ & $100.0^{\mathrm{a}}$ & $100.0^{\mathrm{a}}$ \\
\hline 0.1 & 0.1 & $100.0^{\mathrm{a}}$ & $100.0^{\mathrm{a}}$ & $100.0^{\mathrm{a}}$ & $100.0^{\mathrm{a}}$ & $100.0^{\mathrm{a}}$ & $100.0^{\mathrm{a}}$ \\
\hline
\end{tabular}

Note: The values followed by different letters are significantly different at the $\mathrm{P}<0.05$ level according to the LSD test.

Contrary to that, in this studythe concentration of MS salts did not influence shoot regeneration, but it had an impact onthe mean number of shoots and nodes per explant and better results were achieved on MS media (Table 2), like in the case of the micropropagation of $D$. Serotinus (Marković et al. 2013a). Differences among explant types were also observed, and the shoot 
cuttings had the highest number of newly developed shoots (15.4) and nodes (9.7) on the MS medium containing $0.5 \mathrm{mg} / \mathrm{L}$ BAP and 0.1 mg/L NAA. The concentration of BAP affected the mean number of shoots per explant,in the most cases causing better results on the media with $0.5 \mathrm{mg} / \mathrm{L}$ BAP than on the ones with 1.0 or $0.1 \mathrm{mg} / \mathrm{L}$ BAP. However, statistically significant difference was recorded only forshoot cuttings, and for terminal buds on MS medium. Similarly, a stastistically significant influence of BAP concentration on the number of shoots was recorded for some other Dianthus species, including $D$. deltoides, $D$. gratianopolitanus, $D$. giganteus banaticus, $D$. spiculifolius, and $D$. henteri (Fraga et al. 2004; Marković et al.2013b;
Pop and Pamfil 2011). However,itsoptimum concentration differed depending on the species. Fraga et al. (2004) found that cytokinin concentration significantly affected the mean number of nodes inD. gratianopolitanus, althoughthat was not the case in this research, as themean number of nodes did notchange significantly with different BAP concentrations (Table 2) added to the media. Similarly, during the micropropagation of Nepeta rtanjensis, themean number of nodes did notchange significantly, when BAP concentration was increased from $0.05 \mathrm{mg} / \mathrm{L}$ to $1.0 \mathrm{mg} / \mathrm{L}$ (Mišić et al. 2005).

Table 2- The average number of shoots and nodes developed at the multiplication stage

\begin{tabular}{|c|c|c|c|c|c|c|c|}
\hline \multirow{2}{*}{$\begin{array}{l}\text { BAP } \\
\mathrm{mg} / \mathrm{L}\end{array}$} & \multirow{2}{*}{$\begin{array}{l}\text { NAA } \\
\mathrm{mg} / \mathrm{L}\end{array}$} & \multicolumn{2}{|c|}{ single node cuttings } & \multicolumn{2}{|c|}{ terminal buds } & \multicolumn{2}{|c|}{ shoot cuttings } \\
\hline & & $1 / 2 \mathrm{MS}$ & MS & 1/2MS & MS & $1 / 2 \mathrm{MS}$ & MS \\
\hline \multicolumn{8}{|c|}{ No. of shoots per explant } \\
\hline 1.0 & 0.5 & $2.7^{\mathrm{bc}}$ & $6.5^{\mathrm{a}}$ & $5.3^{\mathrm{ab}}$ & $6.5^{\mathrm{ab}}$ & $7.1^{\mathrm{abc}}$ & $9.1^{\mathrm{abc}}$ \\
\hline 1.0 & 0.1 & $2.5^{\mathrm{bc}}$ & $5.9^{\mathrm{ab}}$ & $4.8^{\mathrm{bc}}$ & $6.3^{\mathrm{ab}}$ & $6.7^{\mathrm{bc}}$ & $8.3^{\mathrm{bc}}$ \\
\hline 0.5 & 0.5 & $3.0^{\mathrm{bc}}$ & $6.9^{\mathrm{a}}$ & $5.8^{\mathrm{ab}}$ & $6.5^{\mathrm{ab}}$ & $9.4^{\mathrm{ab}}$ & $12.1^{\mathrm{ab}}$ \\
\hline 0.5 & 0.1 & $5.1^{\mathrm{a}}$ & $6.0^{\mathrm{ab}}$ & $5.9^{\mathrm{ab}}$ & $7.2^{\mathrm{a}}$ & $10.3^{\mathrm{a}}$ & $15.4^{\mathrm{a}}$ \\
\hline 0.1 & 0.1 & $4.1^{\mathrm{ab}}$ & $4.6^{\mathrm{ab}}$ & $6.9^{\mathrm{a}}$ & $4.7^{\mathrm{bc}}$ & $6.0^{\mathrm{bc}}$ & $7.0^{\mathrm{bc}}$ \\
\hline \multicolumn{8}{|c|}{ No. of nodes per explant } \\
\hline 1.0 & 0.5 & $2.5^{\mathrm{ab}}$ & $7.1^{\mathrm{a}}$ & $3.2^{\mathrm{a}}$ & $6.8^{\mathrm{ab}}$ & $2.7^{\mathrm{a}}$ & $6.5^{\mathrm{b}}$ \\
\hline 1.0 & 0.1 & $2.7^{\mathrm{ab}}$ & $3.4^{\mathrm{c}}$ & $1.5^{\mathrm{b}}$ & $5.2^{\mathrm{bc}}$ & $1.3^{\mathrm{c}}$ & $6.2^{\mathrm{b}}$ \\
\hline 0.5 & 0.5 & $3.0^{\mathrm{a}}$ & $6.6^{\mathrm{a}}$ & $1.2^{\mathrm{b}}$ & $6.9^{\mathrm{ab}}$ & $1.5^{\mathrm{c}}$ & $9.5^{\mathrm{a}}$ \\
\hline 0.5 & 0.1 & $1.0^{\mathrm{c}}$ & $6.2^{\mathrm{ab}}$ & $2.1^{\mathrm{ab}}$ & $8.5^{\mathrm{a}}$ & $1.3^{\mathrm{c}}$ & $9.7^{\mathrm{a}}$ \\
\hline 0.1 & 0.1 & $1.4^{\mathrm{c}}$ & $6.0^{\mathrm{ab}}$ & $1.1^{\mathrm{b}}$ & $8.3^{\mathrm{a}}$ & $1.6^{\mathrm{bc}}$ & $8.2^{\mathrm{ab}}$ \\
\hline
\end{tabular}

Note: The values followed by different letters are significantly different at the $\mathrm{P}<0.05$ level according to the LSD test.

In contrast to the results obtained for $D$. gratianopolitanus, whose internode length was significantly influenced by the type of explant (shoot tip or node explants) (Fraga et al. 2004), the average internode length in this studyranged from 2.0 to $4.2 \mathrm{~mm}$ and was unaffected by the explant type and the concentration of MS salts (Table 3). Although the impact of hormone concentration was not statistically significant in most cases, internodes were the longest on the medium supplemented with $0.1 \mathrm{mg} / \mathrm{L}$ BAP and $0.1 \mathrm{mg} / \mathrm{L}$ NAA (Table 3). Contrary to that, phytohormone concentration significantly influenced internode length during the micropropagation of $D$. deltoides and D. gratianopolitanus (Fraga et al. 2004; Marković et al. 2013b).

Since their lengths were highly variable, the shoots were placed in threelength categories (less than $10 \mathrm{~mm}, 10-20 \mathrm{~mm}$ and more than 20 $\mathrm{mm}$ ), while the number of shoots belonging to a certain length category was expressed as a percentage of the total number of shoots (Fig. 1). Evidently the concentration of hormones affected shoot length, as with an increase in NAA concentration and a decrease in BAP concentration the percentage of shoots shorter than $10 \mathrm{~mm}$ decreased, whereas the percentage of shoots longer than $20 \mathrm{~mm}$ increased. A higher percentage of long shoots $(>20 \mathrm{~mm})$ was recorded on MS medium than on half-strength MS medium (Fig. 1), which was similar to the response observed during the micropropagation of $D$. deltoides, $D$. petraeus ssp. noeanus, $D$. superbus, and D. giganteiformis ssp. kladovanus (Radojević et al. 1997;Mikulík 1999; Marković et al. 2006; 2013b). 

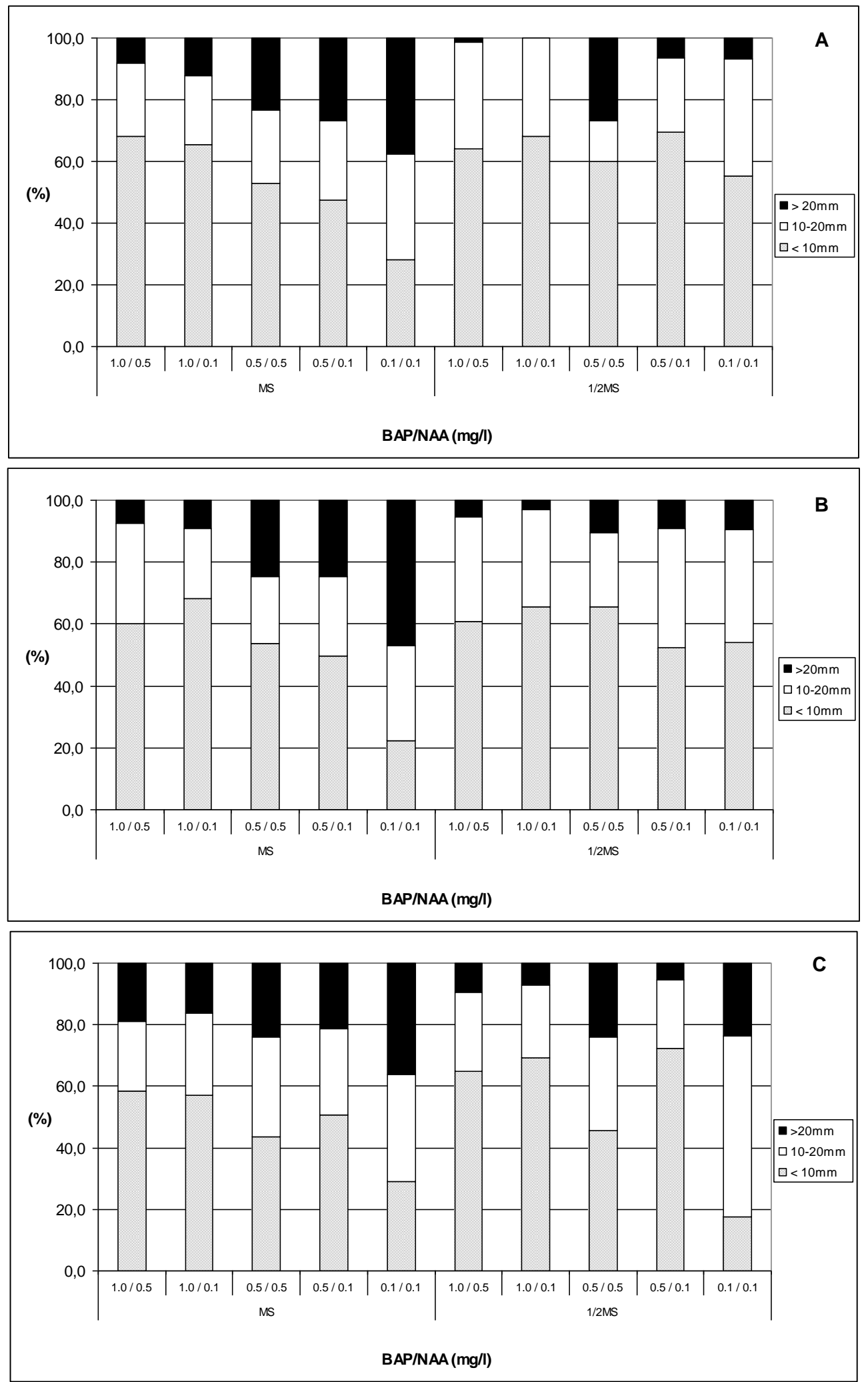

Figure 1- The effect of different concentrations of BAP and NAA on the length of shoots developed from single node cuttings (A), terminal buds (B) and shoot cuttings (C) on full-strength MS basal medium (MS) and half-strength MS basal medium (1/2MS). 
However, the stimulatory effect of NAA on shoot elongation was missing in the case of the propagation of $D$. henteri, $D$. giganteus banaticusand $D$. spiculifolius.In these species, thelongest shootsdeveloped on the media supplemented with 1.0 or $2.0 \mathrm{mg} / \mathrm{L} \mathrm{BAP}$ and 0.1 NAA, whereas the shortest onesappeared onthe medium with $1.0 \mathrm{mg} / \mathrm{L} \mathrm{BAP}$ and $0.5 \mathrm{mg} / \mathrm{L} \mathrm{NAA}$ and in the control without plant hormones
(Popand Pamfil 2011). It is known that different cytokinins can affect shoot length differently, and Marcu et al. (2006) revealedtwice as high shoot length inD. pyrenaicus onthe medium containing $1.0 \mathrm{mg} / \mathrm{L}$ BAP compared to the one obtained on the medium containing $1.0 \mathrm{mg} / \mathrm{L}$ ofkinetin,with the addition of the same NAA concentration $(0.5 \mathrm{mg} / \mathrm{L})$ in both cases.

Table 3- The average internode length of shoots developed at the multiplication stage

\begin{tabular}{cccccccc}
\hline BAP & NAA & \multicolumn{2}{c}{ single node cuttings $(\mathrm{mm})$} & \multicolumn{2}{c}{ terminal buds $(\mathrm{mm})$} & \multicolumn{2}{c}{ shoot cuttings (mm) } \\
\cline { 3 - 8 } & mg/L & $1 / 2 \mathrm{MS}$ & $\mathrm{MS}$ & $1 / 2 \mathrm{MS}$ & $\mathrm{MS}$ & $1 / 2 \mathrm{MS}$ & MS \\
\hline 1.0 & 0.5 & $3.2^{\mathrm{ab}}$ & $3.0^{\mathrm{ab}}$ & $2.9^{\mathrm{b}}$ & $3.3^{\mathrm{ab}}$ & $3.1^{\mathrm{b}}$ & $3.0^{\mathrm{b}}$ \\
\hline 1.0 & 0.1 & $2.3^{\mathrm{b}}$ & $2.2^{\mathrm{b}}$ & $2.3^{\mathrm{bc}}$ & $2.0^{\mathrm{c}}$ & $2.5^{\mathrm{bc}}$ & $2.2^{\mathrm{bc}}$ \\
\hline 0.5 & 0.5 & $3.1^{\mathrm{ab}}$ & $3.1^{\mathrm{ab}}$ & $2.7^{\mathrm{b}}$ & $2.9^{\mathrm{ab}}$ & $2.7^{\mathrm{bc}}$ & $3.2^{\mathrm{b}}$ \\
\hline 0.5 & 0.1 & $2.5^{\mathrm{b}}$ & $2.3^{\mathrm{b}}$ & $2.4^{\mathrm{bc}}$ & $2.6^{\mathrm{b}}$ & $2.4^{\mathrm{c}}$ & $2.4^{\mathrm{bc}}$ \\
\hline 0.1 & 0.1 & $3.9^{\mathrm{a}}$ & $4.2^{\mathrm{a}}$ & $4.1^{\mathrm{a}}$ & $3.8^{\mathrm{a}}$ & $3.8^{\mathrm{a}}$ & $4.0^{\mathrm{a}}$ \\
\hline
\end{tabular}

Note: The values followed by different letters are significantly different at the $\mathrm{P}<0.05$ level according to the LSD test.

Successful rooting, with a high $96.7 \%$ of rooted shoots, was recorded on the MS medium containing $1.0 \mathrm{mg} / \mathrm{L}$ NAA (Table 4). Similarly, a high rooting percentage has already been reported for other Dianthus species, including $D$. superbus ssp. superbus - $100 \%$, D. mainensis $100 \%$, D. deltoides - 100\%, D. giganteiformis ssp. kladovanus - 94\%, and D. petraeus ssp. noeanus - 91\% (Radojević et al. 1997;Mikulik 1999; Marković et al. 2006; 2013b;Erst et al.2014). However,it was much lower for some other species, i.e.D. gratianopolitanus 'Spotti' $80 \%$, D. gratianopolitanus 'Frosty Fire' - $70 \%$ (Fraga et al. 2004) andD. caryophyllus (62 - 80 $\%$ ) (Radojević et al. 1990). The impact of the concentration of MS salts on rooting was obvious, since the rooting percentage was higher on MS media (88.3 - 96.7\%) than on halfstrength MS media (78.4-85.0\%). The addition of NAA to the medium also showeda stimulative effect on rooting by increasing the rooting

Table 4- The percentage of rooted shoots, the average number of roots and the mean length of the longest root per explant.

\begin{tabular}{|c|c|c|c|c|}
\hline $\begin{array}{l}\text { NAA } \\
(\mathrm{mg} / \mathrm{L})\end{array}$ & Medium & Rooting percentage (\%) & $\begin{array}{l}\text { No. of roots per } \\
\text { explant }\end{array}$ & $\begin{array}{c}\text { Mean length of the longest } \\
\text { root }(\mathrm{mm})\end{array}$ \\
\hline 0.0 & MS & $88.3^{\mathrm{ab}}$ & $14.3^{\mathrm{a}}$ & $38.2^{\mathrm{a}}$ \\
\hline 0.1 & MS & $86.7^{\mathrm{ab}}$ & $15.6^{\mathrm{a}}$ & $36.2^{\mathrm{a}}$ \\
\hline 0.5 & MS & $95.0^{\mathrm{a}}$ & $15.1^{\mathrm{a}}$ & $31.5^{\mathrm{a}}$ \\
\hline 1.0 & MS & $96.7^{\mathrm{a}}$ & $16.8^{\mathrm{a}}$ & $33.5^{\mathrm{a}}$ \\
\hline 0.0 & $1 / 2 \mathrm{MS}$ & $78.4^{b}$ & $10.3^{\mathrm{ab}}$ & $22.1^{b}$ \\
\hline 0.1 & $1 / 2 \mathrm{MS}$ & $78.4^{b}$ & $9.8^{\mathrm{ab}}$ & $26.4^{\mathrm{ab}}$ \\
\hline 0.5 & $1 / 2 \mathrm{MS}$ & $83.4^{b}$ & $11.8^{\mathrm{ab}}$ & $28.8^{\mathrm{ab}}$ \\
\hline 1.0 & $1 / 2 \mathrm{MS}$ & $85.0^{\mathrm{ab}}$ & $12.5^{\mathrm{a}}$ & $27.0^{\mathrm{ab}}$ \\
\hline
\end{tabular}

Note: The values followed by different letters are significantly different at the $\mathrm{P}<0.05$ level according to the LSD test. percentage, but no effect on the number and length of roots (Table 4). The effect of the concentration of MS saltswas also recorded for D. mainensis (Erst et al. 2014),but in that case, the rooting was higher on the half-strength MS medium (100\%) than on the MS medium (64\%). Although during the micropropagation of $D$. serotinus, therooting rate was also higher on half-strength MS media, the mean number of roots per explant was higher on MS media (Marković et al. 2014). In thisstudy, neither NAA concentration nor the concentration of MS salts had an impact onthe mean number of roots, ranging from 9.8 to 16.8 , which couldbe considered high compared to the mean number of rootsof up to eightin $D$. mainensis, $D$. petraeus ssp. noeanus, D. gratianopolitanus, D. ciliatus ssp. dalmaticus, D. giganteus ssp. croaticus (Radojević et al. 1997; 2010;Fraga et al. 2004; Erst et al. 2014). 
The obtained acclimatization rate of $88.9 \%$ can be regarded as satisfactory, beingsimilar to the onesrecorded for other Dianthus species, i.e.,D. mainensis - $83 \%, \quad D$. trifasciculatus ssp. parviflorus, D. arenarius ssp. bohemicus - 85\%, D. gratianopolitanus - over $99 \%, D$. petraeus ssp. noeanus - $100 \%$, and D. deltoides - $100 \%$ (Kovác1995; Radojević et al. 1997; Fraga et al. 2004; Marković and Popović 2012; Holobiuc et al. 2013).

\section{CONCLUSIONS}

From the results it was concluded that the endangered and decorative species $D$. pinifolius could be successfullypropagated using the protocol presented in this work. In the course of D. pinifolius micropropagation, MS medium should contain $0.5 \mathrm{mg} / \mathrm{L} \mathrm{BAP}$ and $0.1 \mathrm{mg} / \mathrm{L}$ NAA, while the type of explant used should be shoot cuttings. In addition to that, MS medium supplemented with $0.1 \mathrm{mg} / \mathrm{L}$ NAA should be used forin vitro rooting, followed by the acclimatization of the rooted plantlets, whichwas successful in a 1: 1 mixture of peat and sand.

\section{ACKNOWLEDGMENTS}

This work was supported by the Ministry of Education and Science of the Republic of Serbia within the project no. 43007 for the period 20112015.

\section{REFERENCES}

Cristea V, Brummer AT, Jarda L, MiclăuşM. In vitro culture initiation and phytohormonal influence on Dianthus henteri - a Romanian endemic species. Rom Biotech Lett. Suppl. 2010; 15(1):25-33.

Cristea V. Photoautotrophic in vitro culture of endemic and endangered Dianthus species from Romania. Cluj-Napoca: Todesco, 2010.

Erst AA, Erst AS, Shaulo DN. In vitro Propagation of Dianthusmainensis, an Endemic Plant from the West Sayan (North Asia). Taiwania. 2014; 59(2): 106- 110

Fraga M, Mertxe A, Ellul P, Borja M. Micropropagation of Dianthus gratianopolitanus. Hort Sci. 2004; 39 (4): 112115.

FrankAB, LarsonKL. Influence of oxygen, sodium hypochlorite, and dehulling on germination of green needlegrass seed. Crop Sci.1970; 10 (6): 679682.

Gajić M. GenusDianthus L. In:Josifović M. Editor. Flora SR Srbije. Belgrade: SANU, 1970.

Holobiuc I, Blîndu R. Improvementof themicropropagation and in vitro medium -term preservationof some rare Dianthus species. Contrib Bot. 2006; 41(2): 143 - 151.

Holobiuc I, Blîndu R, Cristea V. Researches concerning in vitro conservation of the rare plant species Dianthus nardiformis Janka. Biotechnol Biotech Eq. 2009; 23(2): 221-224.

Holobiuc I, Catana R, Cristea V. Researches concerning in vitro cultures optimization of the vulnerable species Dianthus nardiformis Janka. AnaleleUniv Oradea - Fasc Biol. 2010b; 17(1): 116-121.

Holobiuc I, Mitoi M, Blindu R, Helepciuc F. The establishment of an in vitro gene bank in Dianthus spiculifolius Schur. and D. glacialis ssp. gelidus (Schott Nym. et Kotschy) Tutin: II. Medium-term cultures characterization in minimal growth conditions. Rom Biotech Lett. 2010a; 15 (2): 5111-5119.

Holobiuc I, Catană R, Voichiğă C, Helepciuc F. In vitro introduction of Dianthus trifasciculatus Kit ssp. parviflorus as ex situ preservation method. Oltenia - Stud Comun Stiint Nat. 2013; 29: 93-100.

Kovác J. Micropropagation of Dianthus arenarius subsp. bohemicus - an endangered endemic from the Czech Republic. Bot Gardens Microprop News. 1995; 8: 106-108.

Lee YI, Lu CF, Chung MC, Yeung EC, Lee N. Developmental changes in endogenous abscisic acid concentrations and asymbiotic seed germination of a terrestrial orchid, Calanthe tricarinata Lindl. J Am Soc Hort Sci. 2007; 132: 246-252.

Marcu D, Cristea V, Butiuc-Keul A. Micropropagation of Dianthus pyrenaicus Pourr. endemic species from Pyrenean Mountains. Contrib Bot. 2006; 41(2): 153-159.

Marković M. New trends in landscaping and gardening as a method for preserving biodiversity. Nature Conservation. 2013; 63(1-2): 25-33.

Marković M, Grbić M, Šindelić A. Possibility of micropropagation of Dianthus giganteiformis ssp. kladovanus (Degen) Soo by the method of proliferation of lateral shoots. Bull Fac For. 2006; 94:171-179.

Marković M, Grbić M, Skočajić D, Đukić M. Effect of explant type on the rooting and acclimatization of Dianthus serotinus Waldst. \& Kit. Bull Fac For. 2014;109: 125-136.

Marković M, Grbić M, Skočajić D, ĐunisijevićBojović D. The effect of phytohormone balance on shoot multiplication and rooting of the 
species Dianthus serotinus Waldst. et Kit.Bull Fac For. 2007; 95: 83-94.

Marković M, Grbić M, Djukić M. Micropropagation of the Endangered and Decorative Species Dianthus serotinus Waldst. et Kit. Not Bot Horti Agrobo. 2013a; 41(2): 1-8.

Marković M, Popović M, Vilotić D. Micropropagation of Dianthus deltoides L. through shoot tip and nodal cuttings culture. Archives of Biological Sciences. 2013b; 65(1): 17-22.

Marković M, Popović M. Effect of explant type, medium and soil mixture content on Dianthus deltoides L. rooting and acclimatization. Bull Fac For. 2012; 105: 117-126.

MiclăuşM, Cristea V, Deliu C. Micropropagation on Dianthus petraeus W. et K. ssp. simonkaianus (Peterfi) Tutin.Contrib Bot. 2003; 38: 77-84.

Mikulík J. Propagation of endangered plant species by tissue cultures. Acta Univ Palack Olom Bio. 1999;37: 27-33.

Mišić D, Ghalawenji N,Grubišić D, Konjević R. Micropropagation and Reintroduction of Nepeta rtanjensis, an Endemic and Critically Endangered Perennial of Serbia. Phyton. 2005; 45: 9-20.

Miyoshi K, Mii M. Enhancement of seed germination and protocorm formation in Calanthe discolor (Orchidaceae) by $\mathrm{NaOCl}$ and polyphenol absorbent treatments.Plant Tiss Cult Lett.1995; 12: 267-272.

Miyoshi K, Mii M. Stimulatory effects of sodium and calcium hypochlorite, pre-chilling and cytokinins on the germination of Cypripedium macranthos seed in vitro. Physiol Plantarum.1998; 102: 481486.

Murashige T, Skoog F. A revised medium for growth and bioassays with tobacco tissue culture.Physiol Plantarum.1962; 15: 473-497.

Pence VC. The application of biotechnology for the conservation of endangered plants, Chapter 15. In: Benson E.E. Editor.Plant Conservation Biotechnology.London:Taylor and Francis;1999. p. 227-241.
PopT, PamfilD. In vitro Preservation of Three Species of Dianthus from Romania. Bull UASVM Hort. 2011;680: 414-422.

Popović M, Grbić M, Marković M. Propagation of Dianthus deltoides L. by shoot culture. Bull Fac For. 2008; 97: 209-219.

Radojević Lj, Ćalić-Dragosavac D, Špirić J, Stevanović B, Stevanović V. In vitro culture of stem segments of Dianthus ciliatus ssp. dalmaticusand $D$. giganteus ssp. croaticus (Caryophyllaceae). Bot Serbica. 2010; 34(2): 153 161.

Radojević Lj, Marinković N, Jevremović S.Vegetative in vitro propagation of Dianthus petraeus Waldst. et Kit. subsp. noeanus bymeristem and stem segments culture. Arch Biol Sci.1997; 31: 73-77.

Radojević Lj, Špirić J, Stevanović B, Stevanović V. In vitro culture of several endemic species Dianthus in Balkan Peninsula. XXII International Symposium Section Ornamentals, 2006, Sanremo, Italy:September 11-15, 2006.p.36.

Ranđelović V, Zlatković B, Milosavljević V, Ranđelović N. The endemic flora of Bosilegrad surroundings (Krajište region) in SE Serbia. Phytol Balcanica. 2008; 14(3): 367 - 375.

Tomović G, Ranđelović V, Niketić M, Vukojičić S, Zlatković B. New distribution data of some Pontic and submediterranean plant species in Serbia. Arch Biol Sci. 2003; 55 (1-2): 45-54.

Received: June 02, 2015; Accepted: January 29, 2016. 